\title{
Hispanic Roofer's Fall Protection Failed Causing Him to Fall 29.91 Feet to His Death
}

\section{Incident Number: 14KY030}



Photo \#1 building with scaffold where victim was working

Photo courtesy of KY OSHA

Kentucky Fatality Assessment and Control Evaluation Program Kentucky Injury Prevention and Research Center 333 Waller Avenue

Suite 242

Lexington, Kentucky 40504

Phone: 859-323-2981

Fax: 859-257-3909

www.kiprc.uky.edu

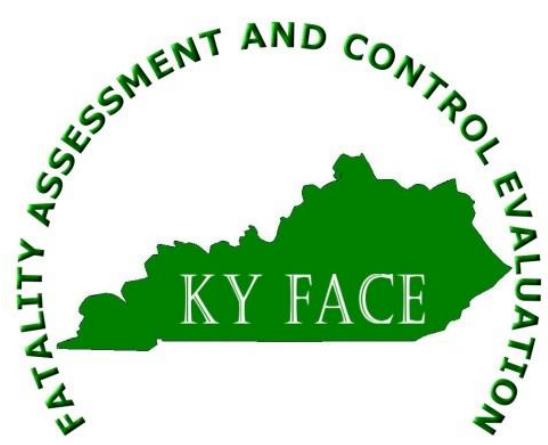




\section{Kentucky Fatality Assessment and Control Evaluation (FACE) Program Incident Number: 14KY030 \\ Release Date: March 9, 2015 \\ Subject: Hispanic Roofer's Fall Protection Failed Causing Him to Fall 29.91 \\ Feet to His Death}

\section{$\underline{\text { Introduction }}$}

On Monday, June 30, 2014 at 11:48 am a 60-year-old Hispanic roofer was removing shingles from a church roof. As he leaned back on the leading edge of the roof, his safety rope snapped, causing him to fall 29 feet 11 inches to hard dirt below. Although the victim was wearing a safety harness, it was not considered a personal protection fall arrest system and he was not tied off properly. Emergency services were called and the victim was in cardiac arrest when emergency personnel arrived. The victim died 20 minutes later in the hospital from injuries sustained from the fall.

To prevent future occurrences of similar incidents, the following recommendations have been made:

Recommendation No. 1: Roofing industry employers must train their roofers in fall protection including how to wear and how to inspect their equipment for defects. ${ }^{1}$

Recommendation No. 2: Employers must ensure that worker safety is adopted by all employees from the top management down to laborers.

Recommendation No.3: Kentucky OSHA enforcement regulations must be stricter for repeat offenders and willful citations. ${ }^{2}$

Recommendation No 4: Employers should provide written worker safety programs as well as ensure that all employees are annually trained on safety programs including the use and care for personal protection equipment. ${ }^{3}$

\section{$\underline{\text { Employer }}$}

The employer was a roofing contractor offering a complete selection of roofing and gutter services for every type of roof, from shingles to tile. The company provides new roofs, repairs and gutter installation as well as asphalt shingles, EPDM flat roofs, and metal roofs. The employer has 6 employees.

\section{Written Safety Programs and Training}

The employer did not provide any written worker safety programs in accordance with OSHA requirements. There was no documented training for the employees including fall protection. 


\section{$\underline{\text { Victim }}$}

The victim was a 60-year-old, Hispanic male roofer who had been employed with the company for 10 years. He had an education level of eighth grade or less. He was born in Mexico, and English was his second language.

\section{Incident Scene}

The scene was a church roof in a metropolitan city. The eave-to-ground distance was measured to be 29.91 feet and the pitch was 9/12. The distance between the north and south eave was 24 feet.

\section{Weather}

Monday, June 30, 2014 was an overcast day with temperatures ranging from 79 to 87 degrees Fahrenheit. The forecast indicated that there was a possibility of rain showers in the afternoon hours. One co-worker made the statement that the crew was in a rush to get finished before it rained.

\section{Investigation}

The Kentucky Fatality Assessment and Control Evaluation Program was notified by the Kentucky Labor Cabinet of an occupational fatality involving a roofer. An investigation into the fatality was opened and conducted.

On Monday, June 30, 2014, at 11:48 am, a 60-year-old Hispanic roofer and five co-roofers were replacing a roof on a church. This was their second week on the job. The roofers were all on a 9/12 pitched shingled roof on the south end of the structure. They were in the process of tearing off the old shingles and laying out the felt paper. The victim was working on the leading edge. Employees interviewed stated the victim was wearing a safety harness which was secured via nylon rope to a temporary anchor affixed to the ridge line of the roof. It is unclear if the victim was leaning back away from the ridge line with tension applied to the rope or was holding the rope taut while he worked. The victim was situated near the box gutter on the leading edge when the rope snapped and he fell to the ground below.

Emergency Services were called at 11:48 am, and the victim was in cardiac arrest when emergency personnel arrived at 11:56 am. He was later pronounced dead at 12:16 pm.

The victim's rope, which showed definite signs of aging and deterioration, appeared to have snapped approximately 12 inches from the rope positioning device (rope grab) (see Photo \#2). The section of the rope where the break occurred was very dry and brittle and pieces were easily torn off with light pressure. The rope severed approximately 11 feet from the anchoring point. The positioning device and snap hook showed signs of rust. (See photo \#3) Other ropes that were onsite also showed signs of wear. 
The rope was a Guardian shock absorbing line serial \#09274. The company who makes the rope was contacted and asked to help determine the age of the equipment and possible causes of failure. The Quality Control Manager for the rope company stated they could not determine with any certainty the age of the rope by the serial number, and the other identifying information was faded or not printed on the rope. The company was not able to track the purchase date of the rope by the serial number. The Quality Control manager did say he estimated the age of the rope to be approximately 4 yrs. old and the likely cause of failure was three-fold:

- Lack of proper maintenance, evident by the rusting position device and snap hook.

- Overstressed; the rope appeared frayed, as if it had been dragged across a sharp edge several times.

- A black mark adjacent to the cut location was also discovered, and its cause is unknown. (see photo\#4)

Prior to this incident, the company had received Kentucky OSH citations on three separate occasions for no fall protection. In this incident, Kentucky OSH cited the company for a willful violation. ${ }^{1}$

\section{Cause of Death}

The cause of death was multiple blunt force injuries sustained in a fall from a height.

\section{$\underline{\text { Recommendations and Discussions }}$}

\section{Recommendation No. 1: Roofing industry employers must train their roofers in fall protection including how to wear and how to inspect their equipment for defects.}

Inspection of the fall protection equipment before commencing work is imperative to ensure the safety of the employees using the safety equipment. Ropes, harnesses, and other fall protection equipment become worn and weakened over time and should be replaced upon first notice of any sign of damage. The victim's rope was clearly worn with a rusted positioning device and snap hook. The rope was very brittle and easily pulled apart. Daily inspection of the fall protection equipment would have identified the rope defects. There were no training records to verify any of the employees had received fall protection and during interviews the employees were not clear on how to wear the fall protection or the ratings for weight. Basic fall protection training was not provided nor were the OSHA standards for working on roofs. OSHA's 1926.503, PFAS subpart M, 1926.501 (b) (10) and 1926.501 (b) (11) explain the standards for working on roofs with lowslopes and steep roofs.

\footnotetext{
1 A willful violation exists under the Act where the evidence shows either an

intentional violation of the Act or plain indifference to its requirements. The

employer committed an intentional and knowing violation if:

1. An

employer representative was aware of the requirements of the Act, or the

existence of an applicable standard or regulation, and was also aware of a

condition or practice in violation of those requirements, and did not abate

the hazard.
} 
Recommendation No. 2: Employers must ensure that worker safety is adopted by all employees from the top management down to laborers.

Three hours after the fatality, employees, including the foreman, were observed back on the roof without proper fall protection. Without management setting an example of leadership by using all PPE available, including fall protection, the employees will remain exposed to hazards. This will result in more injuries and possible fatalities.

\section{Recommendation No. 3: Kentucky OSHA enforcement regulations need to be stricter for repeat offenders and willful citations.}

This employer had been cited three separate times (2006, 2007 and most recently in 2013) for failing to utilize proper personal fall protection on both low- and steep- slope roofs. This fatality that occurred on June 30, 2014, resulted in an OSHA willful violation ${ }^{1}$ citation. . Even though the employees and the foreman had just witnessed the fall of a coworker resulting in his death, they continued their unsafe behavior by working without properly utilizing fall protection.

Recommendation No 4: Employers should provide written worker safety programs as well as ensure that all employees are annually trained on safety programs including the use and care of personal protection equipment.

The KY OSH inspector requested training records for the employees that were working onsite the day of the incident as well as the written safety programs. The employer was unable to produce these vital documents for the inspector. If the employer had written worker safety programs and trained his employees, the incident may have been avoided.

Keywords

Roofing

Fall protection

\section{References and Further Reading}

${ }^{1}$ Fall Protection Information. Fall Protection- It's a Snap! OSHA.

[https://www.osha.gov/Region7/fallprotection/index.html] Date Accessed: December, 2014

${ }^{2}$ C.2.E. Criminal/Willful Violations. OSHA Field Inspection Reference Manual CPL 2.103

Section 7- Chapter III- Inspection Documentation. OSHA.

[https://www.osha.gov/Firm_osha_data/100007.html] Date Accessed: December, 2014.

${ }^{3}$ Sample Programs. Help for Employers. OSHA.

[https://www.osha.gov/dcsp/compliance_assistance/sampleprograms.html] Date

Accessed: December, 2014. 


\section{Acknowledgements}

The Kentucky FACE program would like to thank the Kentucky Labor Cabinet and Kentucky OSHA, the Sheriff's department and the county coroner for their assistance with this report.

The Kentucky Fatality Assessment \& Control Evaluation Program (FACE) is funded by grant 2U60OH008483-10 from the Centers for Disease Control and Prevention and the National Institute for Occupational Safety and Health. The purpose of FACE is to aid in the research and prevention of occupational fatalities by evaluating events leading to, during, and after a work related fatality. Recommendations are made to help employers and employees have a safer work environment. For more information about FACE and KIPRC, please visit our website: www.kiprc.uky.edu 


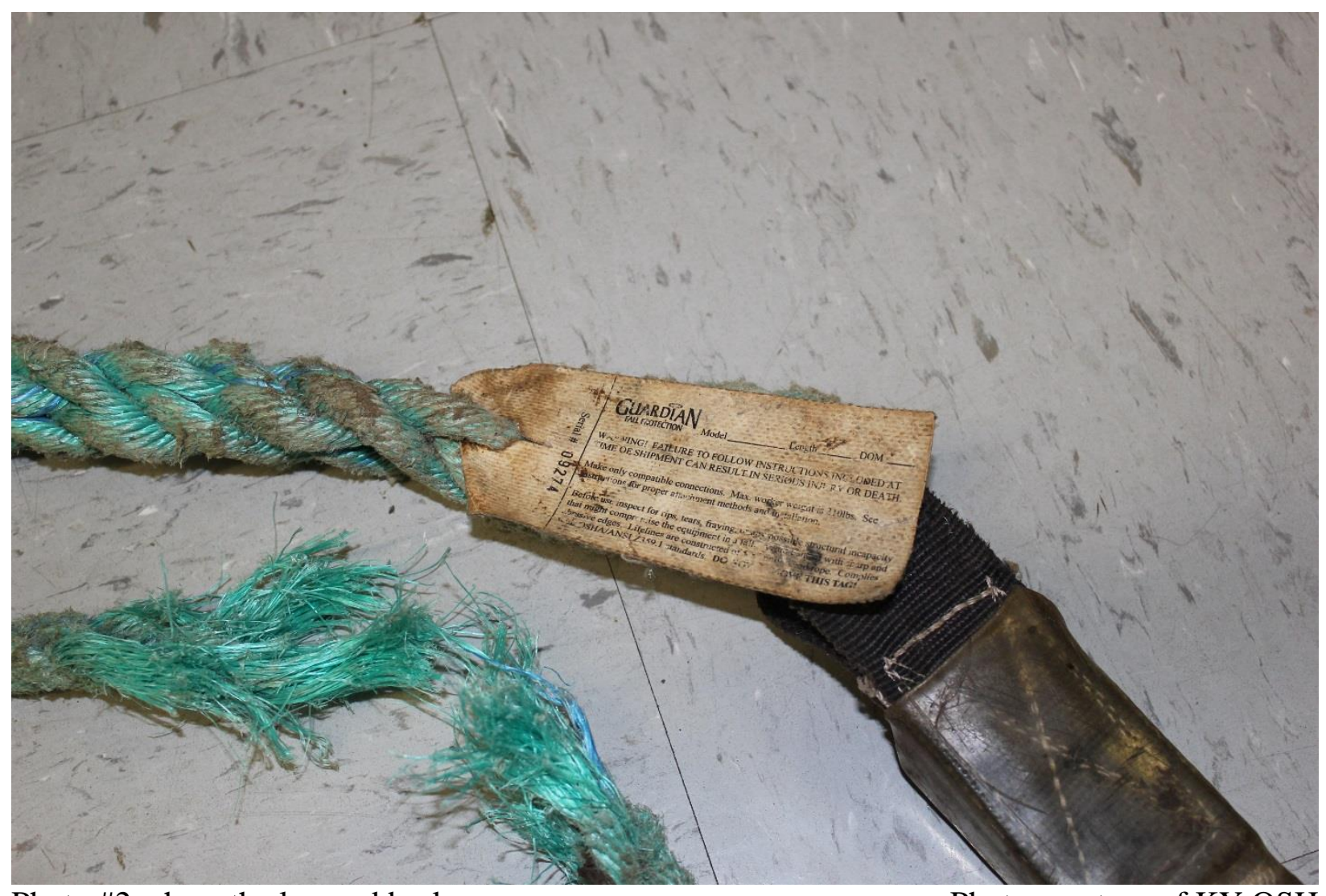

Photo \#2 where the lanyard broke

Photo courtesy of KY OSH 




Photo \#3 the worn lanyard with rust.

Photo courtesy of KY OSH 


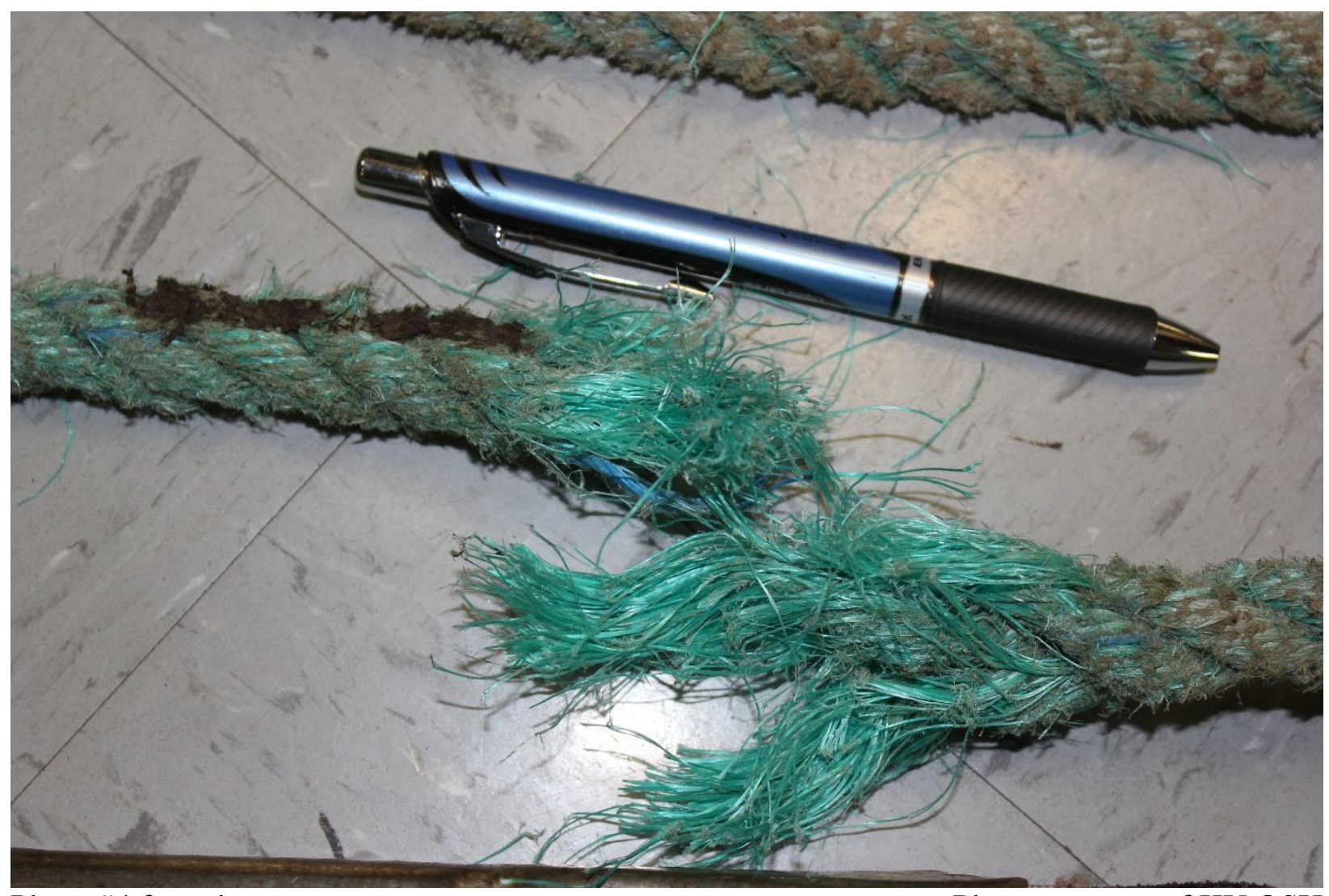

Photo \#4 frayed rope

Photo courtesy of KY OSH 